\title{
What Determines the Severity of Tunneling in China?
}

\author{
Helen Wei Hu and Pei Sun \\ (Final Version, 9 April 2018)
}

\begin{abstract}
This study contextualizes the agency theory perspective in the Chinese setting to better understand the determinants of tunneling by controlling shareholders, a well-known form of principal-principal conflicts in corporate governance. Specifically, we examine how owner identity, managerial agency, and subnational institutional environments individually and collectively shape the severity of tunneling in Chinese publicly listed firms from 2005 to 2010. The empirical analysis shows that local governments and private enterprises tunneled more wealth from their respective listed subsidiaries than central government agencies. Further, the severity of tunneling was greater in companies with higher managerial agency costs, especially those controlled by local governments. Finally, the intensity of tunneling was found to be negatively associated with the institutional quality of the subnational regions in which the listed firms resided, especially those controlled by private entities. Our study serves to enrich the burgeoning literature on PP conflicts in corporate governance research.
\end{abstract}

Keywords: Tunneling, principal-principal (PP) conflicts, agency theory, corporate governance, China. 
“Tunneling” involves the transfer of financial resources from a listed company to its controlling shareholder(s) (Johnson, La Porta, Lopez-de-Silanes, \& Shleifer, 2000), and is a well-known form of principal-principal (PP) conflicts. Tunneling typically arises when two conditions combine: (i) concentrated corporate ownership and control; and (ii) weak institutional protection of minority shareholder rights (Peng \& Sauerwald, 2013; Young, Peng, Ahlstrom, Bruton, \& Jiang, 2008). Previous corporate governance research has shown that country-level legal and regulatory institutions offer varying degrees of minority investor protection, leading to different tunneling propensities around the world (Djankov, La Porta, Lopez-de-Silanes, \& Shleifer, 2008; Peng \& Jiang, 2010). However, to date, inadequate research has been conducted on within-country variations in tunneling (Durnev \& Kim, 2005; Young et al., 2008). Thus, this study aims to address the following questions: Do firms operating in a weak legal/regulatory regime invariably suffer from tunneling? If not, how do firm-level and institutional-level contingencies explain within-country variations in tunneling?

To address this gap, we draw upon agency theory development in relation to PP conflicts (Dharwadkar, George, \& Brandes, 2000; Young et al., 2008) to highlight the importance of individually and jointly examining three previously understudied governance and institutional factors that influence tunneling: controlling shareholder identity; the managerial agency problem; and subnational institutional environments. By following this integrative approach, we undertake a more contextualized and refined examination of how ownership, management, and institutional environments drive, facilitate, and constrain tunneling in China.

According to agency theory, the central agenda for corporate governance research in emerging economies is to address PP conflicts between controlling and minority shareholders (La Porta, Lopez-de-Silanes, Shleifer, \& Vishny, 2000; Peng \& Sauerwald, 2013; Young et al., 2008). 
Unlike principal-agent (PA) conflicts, which feature managerial opportunism (Jensen \& Meckling, 1976; Shleifer \& Vishny, 1997), PP conflicts are characterized by owner opportunism that can manifest in various forms, such as the appointment of unqualified cronies or family members as senior executives, and the pursuit of projects that advance the private benefits of large shareholders (Anderson \& Reeb, 2004; Schulze, Lubatkin, Dino, \& Buchholtz, 2001).

A less subtle form of PP conflicts involves controlling shareholders' misappropriating corporate wealth at the expense of outside investors. Previous research has primarily focused on agency theory, but has offered limited insights into how the different identities of controlling shareholders shape their tunneling behaviors. This is because the incentive structures of these shareholder groups can be idiosyncratic, and are currently under-contextualized in the conventional agency theory literature. The present study identifies how economic agents' incentives are shaped by specific institutional contexts.

The current literature on PP conflicts also tends to assume away PA conflicts and neglects the potential role of corporate management in tunneling. However, the managerial agency problem is not necessarily negligible in companies with concentrated ownership structures. Further, it is unlikely that controlling shareholders could enforce tunneling without the acquiescence or support of their managers. Therefore, we identify corporate management as the second key element in our study to explore how managers and controlling shareholders interact to determine the intensity of tunneling.

Large emerging economies feature large variations in subnational institutions, which can have a considerable influence on firm behaviors (Shi, Sun, and Peng, 2012; Sun, Qu, and Liao, 2018). Subnational institutional environments matter, because these environmental 
contingencies offer proximate and contextual arrangements that regulate the functioning and enforcement of national institutions and policies regarding minority shareholder protection. The disciplinary effects of such institutional environments may vary across different types of controlling shareholders, who may exhibit different responses to institutional pressures and demands.

China is a suitable empirical setting to study this research theme, as it has largely embraced the Anglo-American style legal frameworks since launching its stock market (Feinerman, 2007). However, a significant gap remains between what the latest Chinese legal rules (as measured by established indices) predict and what actually occurs in the Chinese corporate sector. When measuring the degree of investor protection, the values assigned place China among the most investor-friendly countries in the world (Djankov et al., 2008). However, the media is full of anecdotes of controlling shareholder expropriation, many of which have been confirmed by academic research (Haß, Johan, \& Müller, 2016; Jiang, Lee, \& Yue, 2010; Yiu, Xu, \& Wan, 2014). Accordingly, we need a more contextualized examination of the specific motives of controlling shareholders involved in, and the external constraints on, tunneling.

This research contributes to a deeper understanding of the antecedents of PP conflicts (Peng \& Sauerwalk, 2013; Young et al., 2008). By integrating insights from agency theory and the Chinese institutional context, this study advances understandings of how the severity of PP conflicts in terms of tunneling is individually and jointly determined by different types of controlling shareholders, corporate management, and subnational institutional contingencies. Further, our research shows that specific institutional arrangements can shape the incentives, behaviors, and interactions of economic and political agents in the Chinese corporate governance regime, thus highlighting the importance of linking theories (e.g., agency theory) to 
context in emerging market-based research (Xu \& Meyer, 2013). Finally, this study makes an important empirical contribution in terms of research on corporate governance in China. While prior China-based research largely focused on the effects of large shareholder tunneling on firm outcomes (e.g., Jiang et al., 2010; Jiang \& Kim, 2015), our study is among the first to offer a more nuanced account of how firm-specific and institutional factors shape the varying intensity of tunneling in this emerging economy.

\section{Conceptual Background and Prior Research}

Portrayals of the global landscape of corporate ownership (La Porta, Lopez-de-Silanes, \& Shleifer, 1999) reveal that the traditional image of dispersed shareholder structures is the exception rather than the rule outside the Anglo-American corporate world. Indeed, a large proportion of companies in East Asia and Continental Europe fall under the control of families or the state. Consequently, the main research agenda for corporate governance in the rest of the world concerns agency conflicts between controlling and minority shareholder groups. Previous research has largely focused on cross-national differences in the magnitudes of expropriation, and has shown that the severity of expropriation is negatively associated with the degree of minority investor protection endorsed by country-level legal regimes (La Porta et al., 2000). Legal and regulatory protections serve to significantly raise the costs associated with tunneling by imposing sanctions on controlling shareholders. Conversely, research on within-country determinants of tunneling remains in its infancy.

At the ownership level, previous research has adopted the agency-theoretic approach, recognizing that ownership concentration and the presence of multiple blockholders can affect tunneling. First, if more ownership stakes in a listed firm are concentrated in the largest 
shareholder, the potential benefits of tunneling decrease, because the largest shareholder has to internalize a considerable fraction of the negative consequences from their own fund extraction (Jensen \& Meckling, 1976; Wu, Xu, \& Phan, 2011). Conversely, when the dominant shareholder group holds fewer stakes in a company but retains effective corporate control, opportunism will be heightened because fewer of the negative consequences of tunneling can be imposed on the group itself. Additionally, the presence of multiple blockholders in a public corporation may serve as a check against potential agency abuse by a dominant shareholder group (Faccio, Lang, \& Young, 2001; Sauerwald \& Peng, 2013). As Luo and colleagues (2013) found, tunneling is effectively curbed when there is a medium level of control contestability among multiple blockholders.

Notably missing from the aforementioned ownership-level inquiries is an explication of whether and how different types of controlling shareholders vary in their propensity to tunnel. From a pure agency theory perspective, it is difficult to assert that a certain type of controlling shareholder is a priori more inclined than another type to expropriate minority shareholders. Instead, the incentive structures of different shareholder groups are endogenous to the specific institutional contexts in which they are embedded and shaped by national and subnational institutional contingencies. Thus, controlling shareholders may exhibit different degrees of opportunism in respect of their attitudes toward minority shareholders. Further, different controlling shareholders may not respond to the same set of institutional constraints in the same way. Thus, the disciplinary effects of institutions on tunneling may vary across different shareholder identities.

Another underdeveloped area of research relates to the role of corporate management in PP conflicts. Recent research on PP conflicts has made the implicit assumption that managers will 
necessarily act on behalf of controlling shareholders to expropriate corporate wealth, should the latter group opt to do so. However, this assumption is questionable, as PA and PP conflicts may not be mutually exclusive in public corporations. For example, given potential legal and regulatory sanctions, managers must be motivated to assume the risk of implementing tunneling. Consequently, controlling shareholders may tolerate more managerial opportunism as a motivating device to facilitate their own agency abuses. In this study, we take an initial step toward understanding this issue by examining how PA conflicts may affect the severity of tunneling by different controlling shareholders.

In sum, previous research has examined a variety of ownership and institutional factors driving large shareholder tunneling, but neglects the potential role of managerial agency issues in the management of PP conflicts. Moreover, it lacks a detailed account of how key corporate governance actors (i.e., controlling shareholders) are shaped by specific institutional contexts to conduct such tunneling activities. The next section of this paper introduces the Chinese research setting for this study, and then integrates this setting with the extant literature to develop our hypotheses.

\section{Research Setting}

Opportunism on the part of controlling shareholders is widespread in China because of the initial design of the stock market. In the 1990s, the Chinese government used corporatization and stock flotation as the key measures to transform state-owned enterprises (SOEs) into modern business organizations while maintaining effective state control. Consequently, the stock market became a convenient channel for tapping household savings to finance the distressed SOE sector. In China, SOEs were originally supervised by government agencies 
before corporatization. As a result of restructuring, SOEs were transformed into holding companies, which in turn carved out their profitable assets to establish new corporate entities. The holding companies received controlling stakes for their injection of profitable assets. When a new company obtained approval for a public offering, it received cash from the public while issuing minority shares.

Many private firms also follow a similar "carve-out” listing process. Because China's securities regulation requires that companies achieve an average net return on equity (ROE) of $6 \%$ in the consecutive three years before initial public offerings (IPOs), they have a strong incentive to create new corporate entities that are profitable enough to meet the benchmark (e.g., Jian \& Wong, 2010). While only a handful of private sector firms were listed on the Chinese stock market in the 1990s, the 2000s witnessed the growing importance of the private sector in the Chinese economy.

Due to this carve-out listing process among SOEs and private enterprises, only a thin line remains between the holding company and its listed subsidiary regarding operational, financial, and personnel issues. Many dominant shareholders in the corporatized firms (both state and private) felt little obligation to outside investors. In practice, a large number of tunneling cases have been identified. Among these tunneling activities, the use of a unique Chinese accounting item — other receivables (OREC) — to transfer funds and assets by controlling shareholders has attracted widespread attention from practitioners and academics alike. In China, OREC can be used to record related party transactions (particularly loans to related subsidiaries) or to conceal unfair transactions with related parties. Companies typically engage in OREC-related assets diversion for non-operational purposes. Additionally, companies can manipulate the provision for bad debt through OREC, thus expropriating cash flows that are not reflected in 
the accounting records. Indeed, tunneling through OREC has been under scrutiny by prior empirical studies in the Chinese context (Haß et al., 2016; Jiang et al., 2010; Qian \& Yeung, 2015; Sun, Mellahi, \& Liu, 2011).

Although formal legal rules in China seem to offer investors sound protection against expropriation, such legal constraints can be rather ineffective owing to massive enforcement failures. The official stock market regulator — the China Securities Regulatory Commission (CSRC) - is supposed to enforce a uniform set of legal and regulatory rules on all market participants. In the first decade of this century, the CSRC issued a series of administrative rules to check tunneling behaviors. Specifically, the CSRC can issue administrative sanctions in the form of formal warnings and fines, or even civil and criminal liabilities charges. However, the sanctions were regarded as largely ineffective (Jiang \& Kim, 2015; Liebman \& Milhaupt, 2008). According to Liebman and Milhaupt (2008), the number of sanctions was modest and a majority of them did not result in investor lawsuits. They conclude that "the lack of a class action mechanism to aggregate claims, local favoritism in the courts, uncertain enforcement prospects, political pressure, ...., all work to diminish the viability of the legal system as a means of protecting investors (pp. 943-944).”

The inefficacy of this regulatory approach is related to the dual role of the Chinese Party-state in the listed sector as both regulator and company owner. Given that a variety of central and regional government agencies control publicly listed firms through intermediate holding companies (Liu \& Sun, 2005), there are inherent conflicts of interests between the two roles. That is, the CSRC has limited jurisdiction over the state-controlled entities in the listed firms, even if the latter engage in expropriation of company assets. Students of Chinese politics have long noted that the Chinese Party-state can be characterized as "fragmented authoritarianism" 
(Lieberthal \& Lampton, 1992): In spite of a unitary regime, de facto checks and balances are present among various central and local government agencies.

In the context of securities market regulation, the agency assuming the ownership and control function of the SOEs is the State-owned Asset Supervision and Administration Commission (SASAC), a ministry-level central government agency holding the same bureaucratic rank as the CSRC. Thus, in circumstances where the SASAC has acquiesced in the expropriation of downstream listed companies, it is unlikely that the CSRC would exercise resolute sanctions against these companies. Similarly, it is also difficult for the CSRC to seriously punish companies for self-dealing activities that are ultimately controlled by provincial governments, which have the same rank as the CSRC in the Chinese political system. An additional complicating factor lies in the Party cadre management system that decides which SOEs leaders to appoint and remove. That is, it is the Party organization departments at the central and local levels — not the CSRC — that control the authority of managerial appointment in SOEs (Chan, 2004; Green, 2003). In short, while the CSRC is able to exert regulatory pressure on state-controlled listed firms, this pressure may not be sufficiently strong to force these companies to comply with securities regulations. Therefore, the CSRC-led regulatory constraint is of limited use in curbing tunneling.

\section{Hypotheses Development}

Controlling shareholder identity and tunneling

Prior research is largely silent on whether and how different types of controlling shareholders vary in their propensities to misappropriate firm wealth. In China, a variety of local 
government agencies at the provincial, municipal, and county levels represent the majority of ultimate controllers of the listed SOEs. This is attributable to the decentralized state asset administration system in China that has largely assigned ownership and control rights to regional governments. These local SOEs face fewer policy constraints from the central government and have demonstrated greater market and commercial orientation than their central peers (Li, Cui, \& Lu, 2014).

On the other hand, central SOEs are under the direct control of the central authority through the SASAC. Most of these firms are "national champions" operating in strategic sectors and trying to use stock flotation as a means to transform themselves into modern business corporations (Lin \& Milhaupt, 2013). They also serve as important policy instruments for promoting the strategic goals of the central government (Li et al., 2014).

Local state agencies' motives of expropriating company assets can be understood by the specific incentive structure of local government officials in China. Previous research has suggested that a region's economic performance, such as GDP growth and fiscal revenues during a leader's tenure of office, is an important factor affecting his/her promotion prospects (Li \& Zhou, 2005; Shih, Adolph, \& Liu, 2012). Consequently, local officials may have a vested interest in the continued success of the listed companies in their regions. However, rather than maximizing firm value for all shareholders, they may be tempted to use these firms as an instrument for their own political and financial ends. For example, local politicians may find it beneficial to extract financial resources from listed companies to cross-subsidize other loss-making businesses under their jurisdiction. In doing so, financial resources can be mobilized to prop up unprofitable local businesses and boost short-term contributions to local government coffers. Given the high turnover rate of local government 
officials in China (Huang, 2002), local officials may perform asset transfers to serve their political agendas before they leave their current offices. Consistent with this reasoning, Sun and colleagues (2011) document a dramatic case of tunneling by one local township government.

Unlike their local counterparts, the listed central SOEs were cherry-picked by the central government on the basis of their size, sectorial importance, and profitability. A chief policy goal of the central government has been to transform these firms into modern business corporations via stock flotation. This approach also serves to signal to the public the government's commitment to building a sound corporate governance system in the fledging domestic equity market (Lin \& Milhaupt, 2013). Given this policy initiative, expropriating minority investors in these listed flagship subsidiaries is unlikely to help the senior executives of parent companies and SASAC officials achieve their career goals. Indeed, their promotion prospects may be critically linked to the successful functioning of these showcase companies. For example, leaders of high-performing central SOEs have frequently become senior officials in central or local government agencies (Brødsgaard, 2012). Further, because of the high profile and visibility of these central SOEs, potential abuses in these companies are likely to attract more scrutiny from the CSRC and the media. Thus, the short-term benefits from asset diversion would hardly justify the potential damages to government officials' career development.

Previous research has found a wealth of evidence on tunneling by private controlling shareholders under weak institutions (Bae, Kang, \& Lee, 2006; Faccio et al., 2001). The transformation of the equity market in China has gradually increased the importance of private enterprises (Ding, Zhang, \& Zhang, 2007). The financial benefits of tunneling may be 
more straightforward and powerful for private owners than for government officials, who have to make efforts to translate the indirect benefits into promotion and/or private gains. Further, many domestic Chinese entrepreneurs have managed to cultivate patron-client ties with Chinese government officials (Gold, Guthrie, \& Wank, 2002). The pervading networks of favor exchanges between the private sector and local governments make private players less concerned about receiving possible sanctions for abuses in the securities market. Finally, the volatile business environment in China has resulted in the aforementioned reputational constraint on tunneling being largely ineffective among many private businesses, because a large number of them have developed a "hit-and-run" business attitude (Baumol, 1990). For instance, research has found a higher level of earning management in firms controlled by private entities (Ding et al., 2007). Thus, we hypothesize:

Hypothesis 1: The severity of large shareholder tunneling is greater in companies controlled by local SOEs and private enterprises than in companies controlled by central SOEs.

Managerial agency problem, controlling shareholder identity, and tunneling

Prior agency theory literature suggests that PP and PA conflicts arise in companies with different ownership structures: managerial agency problems are characteristic of widely held public corporations, whereas PP conflicts are the primary concern in companies with concentrated shareholding structures (Shleifer \& Vishny, 1997). Given the assumption that senior executives in these firms mostly are representatives of the controlling shareholders (La Porta et al., 1999), the potential for managerial agency abuses has not received adequate attention in previous studies of PP conflicts. Here, we argue that the two types of agency conflicts can be interrelated in focal companies. It is difficult to imagine that controlling 
shareholders could operationalize the expropriation of corporate wealth without the acquiescence and cooperation of company managers. Thus, an examination of whether corporate managers facilitate or hinder tunneling is in order.

In the Chinese context, senior managers in listed companies are usually appointed by controlling shareholders, whether they are state or private entities. However, the controlling shareholders need to align the managers' interests further by compensating them for the high risk of their involvement in the illegal abuses of company assets. Given the potential criminal and civil liabilities, managers are at risk of becoming scapegoats for the self-dealing activities of the principals (i.e., controlling shareholders), especially when the latter group has strong social and political capital in the corporate sector. Therefore, to obtain and motivate managerial cooperation, controlling shareholders may relax their monitoring role and allow managers to extract their own rents from listed companies. These rents act as de facto side payments to managers. Managerial rent extraction can take a variety of conventional forms, ranging from excessive perquisites and on-the-job consumption to the pursuit of pet projects that advance managers' private interests. To summarize, tunneling can be more serious in companies where controlling shareholders manage to establish a collusive owner-management relationship by awarding managerial agents opportunities to extract corporate wealth.

Further, the strength of the association between tunneling and managerial agency abuses can vary with the degree of which ownership and management are effectively separated. In emerging economies where firm ownership is highly concentrated, controlling shareholders usually appoint themselves or their representatives as managers of their organizations $(\mathrm{Hu}$, Tam, \& Tan, 2010; Young et al., 2008). This is particularly common in companies controlled 
by private entities where the separation between ownership and management is rather limited. In such organizations, the need for using managerial rents to motivate senior managers to cooperate with the controlling shareholders in tunneling is considerably lessened.

Conversely, in companies controlled by SOEs, the separation between state ownership and the management of the listed subsidiaries is significant (Cuervo-Cazurra, 2006; Shleifer, 1998). In fact, owing to ownership concentration and the separation of ownership and control in parent SOEs, these listed subsidiaries encounter multiple agency problems (i.e., both PA and PP problems) (Hu \& Cui, 2014). Furthermore, unlike central SOEs where close monitoring is performed by both the central government and the media to showcase China's national champions, decentralization has made monitoring of the local SOEs ineffective, thereby exacerbating the managerial agency problem. As such, to motivate managers to work with them in undertaking tunneling practices, local SOEs need to "award" greater rents to their managers. Therefore, we hypothesize:

Hypothesis 2: The positive association between large shareholder tunneling and managerial agency costs is stronger in companies controlled by local SOEs than in those controlled by private enterprises and central SOEs.

Subnational institutional environments, controlling shareholder identity, and tunneling

Prior research suggests that institutional environments affect the level of shareholder protection across and within countries (Durnev \& Kim, 2005; La Porta et al., 1999). Large and complex emerging economies exhibit substantial heterogeneity in their regional institutional environments ( $\mathrm{Du}, \mathrm{Lu}, \&$ Tao, 2008; Shi et al., 2012). Although China is a 
unitary state with uniform de jure legal/regulatory frameworks, companies face different degrees of property rights protection, government intervention, and contract enforcement effectiveness across regions between and among coastal and inland areas (World Bank, 2008). Consequently, the strength of institutional and reputational constraints on tunneling is expected to vary among subnational regions.

In regions where legal and regulatory rules concerning investor protection are more strongly enforced, controlling shareholders and managers may elect to expropriate less from their listed companies. In addition, a relatively well-functioning institutional environment nurtures the development of trust relationships and promotes the value of long-term reputations for market participants. Thus, controlling shareholders and managers in regions with relatively strong institutional development may refrain from excessive expropriation and place greater value on long-term wealth creation with outside investors. Moreover, the extant literature is largely silent on whether the constraining effect of external institutions on tunneling will vary with the identity of controlling shareholders. Both local SOEs and private enterprises may be tempted to divert wealth from their listed subsidiaries; however, they would not be equally responsive to regional institutional constraints. Specifically, subnational institutions shape the enforcement of legal and regulatory rules against tunneling.

In China, research has shown that firms with state ownership stakes are favored by local courts and regulatory agencies (Firth, Rui, \& Wu, 2011). Given that legal/regulatory rules are enforced in the province where a company is headquartered, both courts and securities regulatory agencies tend to show leniency toward local SOEs (Liebman \& Milhaupt, 2008). This is because both local SOEs and the rule enforcers belong to the Chinese Party-state and have similar bureaucratic ranks. As such, the local gatekeepers in these legal and regulatory 
agencies will have limited incentives and capabilities to discipline local government controlling shareholders.

On the contrary, private firms do not have such political capital and institutional privileges, so they need to be more responsive to the institutional regulations within their regions. With a lack of institutionalized protection from local Party-state organs, private enterprises may be more susceptible to legal and regulatory sanctions for tunneling than are their local SOE peers. Consequently, we hypothesize:

Hypothesis 3: The negative association between large shareholder tunneling and subnational institutional environments is weaker in companies controlled by local SOEs than in those controlled by private enterprises.

\section{Data, method, and variables}

Sample and analytical approach

The sample comprised 1,311 manufacturing companies listed on the Shanghai and Shenzhen Stock Exchanges. Companies’ financial and corporate governance data were collected from the Chinese Stock Market and Accounting Research (CSMAR) Database for the 2005-2010 period. Companies were excluded if they had been listed on the stock market for less than one year; however, ST (special treatment) companies were not excluded from the sample because such companies may demonstrate both tunneling and managerial agency abuses (Liu \& Lu, 2007). This sample selection procedure resulted in an unbalanced panel dataset of 5,811 firm-year observations. Each continuous variable was winsorized at the $1 \%$ 
level to mitigate the effect of outliers.

The fixed-effects regression model was chosen to exploit the panel nature of the dataset for two reasons. First, it is a suitable tool to estimate the marginal effects of explanatory variables because fixed-effects models can control for all factors that vary across entities but are constant over time and for all factors that vary over time but are constant across entities (Wooldridge, 2002). Consequently, such models can significantly alleviate the potential endogeneity of explanatory variables. Further, the Breusch-Pagan Lagrange Multiplier test suggested that the panel model was preferable to a pooled ordinary least squares model. Second, the Hausman (1978) test was conducted to compare the fixed-effect model with the random-effect model. The results confirmed the preference for the fixed-effects model. Finally, all independent, moderating, and control variables were lagged by one year in all regressions to ensure that a more accurate estimation of the main effects was obtained, and to further mitigate any potential endogeneity problems.

\section{Dependent variable}

Measuring tunneling can be very challenging, because by definition it is precisely what controlling shareholders will try to hide and can take a variety of secretive forms. As described in the research setting section, previous studies on tunneling in China (Haß et al., 2016; Jiang et al., 2010; Qian \& Yeung, 2015) have fortunately identified a rather "transparent" practice that borders on the outright diversion of corporate wealth to controlling shareholders (i.e., intercorporate loans that have been recorded as “other receivables” (OREC) in corporate balance sheets). The transparency lies in the fact that large shareholders usually simply "borrow" the cash from their listed companies (with no interests paid and no definite 
return date). The amount of such borrowings is then recorded on the account of "other receivables” in the listed firm. As Jiang and colleagues (2010, p. 4) observed, this account (i.e., OREC) provided “a minimum direct measure of tunneling.”

Tunneling through OREC was a common practice in Chinese companies during the study period; only 7 of the 5,811 firm-year observations had zero OREC values. The amounts shown in the OREC accounts were not synonymous with tunneling, but large values of OREC did suggest that a considerable amount of corporate cash had been moved to the controlling shareholders. Following previous research, we use ORECTA (the value of OREC scaled by total assets) to measure the severity of tunneling.

Independent variables

To assess whether different types of controlling shareholders affected the severity of tunneling, three dummy variables were constructed: (i) a private enterprise equals 1 if the listed firm was controlled by a private entity, and 0 otherwise; (ii) a local state-owned enterprise (LSOE) equals 1 if the listed firm was ultimately controlled by a local government agency, and 0 otherwise; (iii) a central state-owned enterprise (CSOE) equals 1 if the listed firm was ultimately controlled by a central government agency, and 0 otherwise. The first dummy variable (Private) served as the benchmark group in the subsequent regression analysis. Since 2002, Chinese listed companies have been required by the CSRC to disclose the identity of their ultimate controlling shareholders in their annual reports. This information was collected from the CSMAR database and checked by the authors.

Regarding managerial agency costs, we followed previous studies (e.g., Ang, Cole, \& Lin, 
2000; Singh \& Davidson, 2003) in using a firm's expense ratio (i.e., its selling and administrative expenses scaled by its total sales) to measure the degree of potential self-dealing, perquisite consumption, and shirking by company managers. This ratio has been used frequently in the accounting and finance literature, as it "captures excessive expenses including perk consumption” (Ang et al., 2000, p. 82). Additionally, to undertake a robustness check, each company's selling expenses (i.e., the expenses incurred by a company when selling, marketing, and distributing the goods it produces) were scaled by its total sales (i.e., the selling expense ratio) as an alternative measure of managerial agency costs (Yafeh \& Yosha, 2003).

The National Economic Research Institute (NERI) Index of Marketization in China's provinces, denoted as marketization, was used to measure the quality of subnational market-supporting institutions (Shi et al., 2012; Wang \& Qian, 2011). The yearly NERI Marketization indices assess the quality of market-supporting institutions in China's provinces (Fan, Wang, \& Zhu, 2011). The subnational institutions are appraised across five dimensions: (i) the relationship between the government and the market; (ii) the development of the private sector; (iii) the development of the product market; (iv) the development of the factor market; and (iv) the development of market intermediaries and legal environments. A weighted average of the five dimensions produces the index for each province each year. These indices were matched with the sample companies (i.e., those controlled by private entities and local governments) in the provinces where they were located. However, to accurately ascertain the effect of the subnational institutions, we do not include companies controlled by central SOEs in the regressions. This is because these companies usually operate their businesses at the national level and have subsidiaries across the country, so it is less than relevant to examine the regional marketization effect on these firms. 
Control variables

We controlled for several corporate governance variables that have been well documented in prior literature. The first was ownership concentration, measured as the percentage of cash flow rights controlled by the controlling shareholder of a listed firm (La Porta et al., 1999; Tam \& Hu, 2006). The severity of tunneling is affected by the level of ownership of its controlling shareholder. When the controlling shareholder has significant ownership rights, the motivation for tunneling and the potential private gains from tunneling are significantly reduced. Second, we controlled for chief executive officer (CEO) duality. The dummy variable equaled 1 if the CEO was also the chair of the board of directors of the listed company, and 0 otherwise (Jiang \& Kim, 2015). Board size was also controlled for, and measured by the total number of directors on the board of a listed firm (Hu et al., 2010).

Other firm-level characteristics that could affect the severity of tunneling were also considered. Firm size was measured by the natural logarithm of total assets. The profitability of a listed company was measured by its operating margin (defined as the ratio of the company's operating profit to its sales revenues). The leverage of a listed firm was defined as the ratio of total liabilities to total assets.

\section{Results}

The descriptive statistics and correlation matrix for dependent, independent, and control variables are reported in Table 1 . Table 1 shows that the values of OREC were significant in Chinese listed companies, averaging RMB68 million per firm and accounting for 3\% of the total assets. Moreover, the variance of ORECTA was quite large across the sample firms, 
suggesting that controlling shareholders exhibited varying propensities for expropriation. Further, ownership was highly concentrated in the listed firms with controlling shareholders holding an average of $37.40 \%$ of the company shares. Of the sample companies, half were controlled by local SOEs, $42 \%$ by private firms and the remaining companies by central SOEs. Collinearity diagnostics show that the variance inflation factors for all the variables are less than 2.8, suggesting that multicollinearity is not a concern.

$<$ Insert Table 1 here $>$

Table 2 presents the results of the fixed-effect regression analysis. Model 1 shows how the control variables affect the severity of tunneling. Models 2-4 test the first two hypotheses (H1-H2) using the full sample, and Models 5-6 test H3 (the subnational institutional effect) using the sample companies controlled by private entities and local SOEs. The full model results are presented on Model 7. As stated above, companies controlled by central SOEs were excluded from the examination of the subnational institutional effect in Models 5-7.

$<$ Insert Table 2 here $>$

Hypothesis 1 predicts that tunneling is more severe in companies controlled by local SOEs and private firms than in those controlled by central SOEs. We use private firms as the benchmark group in the regression models. The estimated coefficient in Model 2 shows that local SOEs were no less opportunistic than private firms in fund diversion from their listed subsidiaries; however, on average, central SOEs tunneled less corporate wealth than their local SOE and private sector counterparts $(\mathrm{b}=-0.03, \mathrm{p}<0.001)$. These results are consistent with our prediction, thus supporting Hypothesis 1. 
Hypothesis 2 predicts that the positive association between large shareholder tunneling and managerial agency costs is more pronounced in companies controlled by local SOEs than in those controlled by private enterprises and those by central SOEs. Model 4 demonstrates that the magnitude of rents awarded to managers to motivate their cooperation was significantly higher in companies controlled by local SOEs $(b=0.02, p<0.001)$ than in those controlled by private entities and central SOEs. Thus, our findings support this hypothesis.

In the case of regional institutional environments, Hypothesis 3 predicts that the negative relationship between large shareholder tunneling and subnational institutional environments is weaker and less effective in companies controlled by local SOEs than those by private enterprises. Model 6 reveals that the negative association between regional institutional environments and tunneling was significantly weakened in those controlled by local SOEs (b $=0.007, p<0.05$ ), providing support for Hypothesis 3. However, as the estimated coefficient is relatively small, we caution readers about drawing a strong conclusion regarding the effect of subnational institutional environments on firm tunneling by different types of controlling shareholders. Finally, Model 7 reports the full model results in relation to Hypotheses 2 and 3. The results remain consistent in the full model, and thus we conclude that our findings provide strong support for these hypotheses.

Robustness checks

We have performed additional robustness checks and report the results in Tables 3-5. First, we use each company's selling expense ratio as an alternative measure of managerial agency costs to test Hypothesis 2. Model 1 in Table 3 shows a positive relationship between selling 
expense ratio and ORECTA, and Model 2 shows that this positive relationship was stronger in local SOEs. Thus, the results provide strong support for Hypothesis 2. The full model results are presented in Model 3, which are consistent with the original results reported in Table 2. Further, we add the percentage of independent directors on a board and the number of board sub-committees to control for additional corporate governance effects on tunneling in Table 4. Table 4 shows very similar results to those in Table 2, thereby providing further support for all of the hypotheses.

$<$ Insert Tables 3 and 4 here $>$

As this study used winsorized data to test the hypotheses, we have also performed robustness checks by using unwinsorized data, and report the results in Table 5. Excluding central SOEs from all models, Model 1 in Table 5 shows that by performing the full model test of Hypotheses 1 to 3 using the unwinsorized data, results are similar to the original results reported in Model 7 of Table 2, providing further support for the hypotheses. Model 2 uses selling expense ratio as the measure of managerial agency costs and Model 3 adds the board-level control variables. Results from both models provide consistent findings with those reported in Model 3 of Table 3, and Model 7 of Table 4, respectively.

$<$ Insert Table 5 here $>$

The empirical support for $\mathrm{H} 2$ and $\mathrm{H} 3$ is further corroborated by comparing estimated coefficients in subgroup regressions involving sample companies controlled by local SOEs, private enterprises and central SOEs respectively. In examining the relationship between managerial agency abuse and tunneling in the three subgroups, we have conducted Z-score 
tests to check the statistical differences among the three estimated coefficients in the subsamples. The results strongly confirm that the positive relation in the local SOE subsample is significantly stronger than that in the other two subsamples. Similarly, in examining the effects of subnational institutions on tunneling in the subsamples, the Z-score test result suggests that the institutional effect in the private enterprise subsample is significantly stronger than that in the local SOE subsample. In the interest of space, we do not report the detailed regression and Z-score test results here, but they are certainly available upon request.

The robustness of the findings in Table 2 is also checked by using: (1) two-year lagged data (i.e., independent and moderating variables in year $t-1$ to predict ORECTA in year $t+1$ ); and (2) a balanced panel that included 772 firms with all the required information for the 2005-2010 study period. Both tests provide results that are consistent with those reported in Table 2. Finally, we take into account the fact that some of the sample companies may not have identifiable controlling shareholders. Following the established approach (La Porta et al., 1999, p. 475), we use $10 \%$ as the cutoff point to identify if a shareholders ownership rights are significant enough to exert control. We have found that most of the sample companies had a clearly identifiable controlling shareholder, with only 54 firm-year observations (i.e., 9 firms) where the largest equity owners owned less than $10 \%$ of the companies' outstanding shares. After removing these 54 observations, we obtain similar results to the original ones reported in Table 2. Due to space limits, these results are not reported here but they can be obtained from the authors upon request.

\section{Discussion and Conclusion}


In emerging markets with underdeveloped legal/regulatory systems, corporate governance attributes and subnational institutions can play an important role in affecting the severity of tunneling. Our study contributes to corporate governance research on PP conflicts by undertaking an in-depth investigation into how owner identity, managerial agency problem, and regional institutional environments can individually and jointly shape tunneling in Chinese listed firms. Specifically, we find that central government agencies are less inclined than local government agencies and private entities to tunnel wealth from their listed subsidiaries. Further, the positive association found between tunneling and managerial agency costs, particularly in companies controlled by local government agencies, serves as preliminary evidence for the existence of a collusive relationship between managers and controlling shareholders. Finally, our study shows that, while a higher quality of subnational institutions helps reduce tunneling, this effect is more pronounced in the private sector. These results suggest that private players are quite responsive to their surrounding legal/regulatory institutions, but subnational institutions are less effective at curbing the opportunism of local government officials.

Theoretical contributions

Addressing the paucity of prior research on the antecedents of PP conflicts, we adopt a contextualized agency-theoretic approach to examine how different types of controlling shareholders interact with managers and local institutional environments to expropriate firm wealth in China. Our study advances prior research in two important aspects: First, we highlight the importance of achieving a more contextualized understanding of controlling shareholder identities: the incentive structures and the resulting potential agency abuses on the part of different shareholders can only be properly understood when conventional agency 
logic is combined with an in-depth investigation of specific institutional contexts. Our study calls for more research that can incorporate detailed institutional analysis to advance understanding of specific agency problems.

Second, we add to the extant agency theory literature that tends to overlook the interrelationships between PP and PA conflicts in listed companies. Our study demonstrates that significant agency abuses by managers and controlling shareholders can coexist under concentrated ownership structures. What is more, allowing corporate managers to capture more rent may facilitate rent misappropriation by controlling shareholders. This is particularly the case when significant agency relationships are also present between controlling shareholders and the managers they hire. Thus, our study identifies a new direction for corporate governance research that could further illuminate the intriguing interactions between controlling shareholders and managers in rent distribution and capture.

Our study also sheds light on the broad relationships between corporate governance arrangements and national institutions (Aguilera et al., 2008; Peng \& Jiang, 2010). As this paper illustrates, investigations based solely on formal legal/regulatory rules could lead to incomplete understandings of the realities of investor protection. The role of formal legal/regulatory rules can only be accurately understood in conjunction with the corresponding economic and sociopolitical institutions that affect the very enforcement of these rules. In this sense, the legal system in general and investor protection in particular are not exogenous to economic and sociopolitical infrastructures.

The Chinese experience detailed in this paper indicates that the enforcement of legal/regulatory rules in the securities market is inextricably connected to institutions at both 
the national and subnational levels. Understanding the complex interaction between these rules and institutions requires a solid grasp of institutional knowledge about a given country. Therefore, single-country studies can generate significant insights that cannot be captured by conventional cross-national analysis (Franks, Mayer, \& Rossi, 2009).

At a broader scale, the findings of this study suggests development of a more holistic framework that can integrate ownership, managerial, and institutional elements to better understand the determinants of PP conflicts. As noted earlier, previous research examined a variety of these determinants including ownership concentration, presence of multiple blockholders, and national legal/regulatory regimes. Our research adds new elements to this stream of literature and facilitates a more systematic understanding of these individual and interactive effects on tunneling in the future.

\section{Practical implications}

Tunneling by large shareholders is an abuse of their power that harms not only the interests of the firm and its stakeholders, but also the trust of the general public in the securities market. The results of our study have important practical implications for both firms and policy makers in China and other emerging economies. At the firm level, to protect the interests of minority shareholders and other stakeholders, implementing a code of ethics may be one way to address these agency abuses. For instance, an increased awareness of business ethics can assist boards of directors to improve their monitoring roles, which would serve to reduce the propensity for controlling shareholders' wrongdoing. Cultivating the organizational citizenship behaviors of board members and managers may be another way to improve corporate governance (Yoshikawa \& Hu, 2017). 
This research also has crucial relevance to the development of policies to address tunneling problems in emerging economies. Given considerable within-country variation in tunneling, policy prescriptions for transplanting Anglo-American style corporate governance regulations may be of limited use in curbing tunneling, unless these reforms are accompanied by corresponding changes in corporate governance mechanisms and local institutions that will promote the enforcement of these transplanted rules.

In China, the central government must meet the challenge of changing the "growth-at-any-cost" mentality of local officials by reforming the current cadre evaluation system. At a higher level of state building, the central government needs to find ways of tackling the internal conflicts of interests between the state regulatory agency and government controlling shareholders. That is, effective investor protection requires a strong commitment from Chinese leaders to promote the authority of the CSRC over other state and politically connected private controlling entities in relation to stock market regulation. As suggested in the preceding discussion, local officials may only be effectively constrained after fundamental changes have been made in the incentive structure embedded in the current Chinese Party-state.

Limitations, Generalizability, and Future Research

This study has several limitations, and thus its findings should be generalized cautiously to other contexts. However, these limitations also suggest promising avenues for future research. First, the Chinese context limits our classification of controlling shareholder identities to a coarse private-state dichotomy, so future research in other contexts can explore how other 
blockholders (e.g., family owners and institutional investors) and other ownership arrangements (e.g., business groups) affect PP conflicts.

In many Asia Pacific economies, including Korea and India, family firms and business groups represent dominant organizational forms in their corporate sectors. Future research can explore how family owners' incentives are shaped by their institutional environments and the potential heterogeneity of PP conflicts in family-controlled public corporations (e.g., Peng \& Jiang, 2010). Similarly, business groups have long been identified as a possible device to facilitate tunneling in many Asian economies (Bae et al., 2006; Yiu, Chen, \& Xu, 2013). We believe there are ample future research opportunities in understanding how different types of blockholders in business groups interact with managers to influence tunneling (Cuervo-Cazurra, 2006; Yiu, Lu, Bruton, \& Hoskisson, 2007).

A second promising avenue for future research relates to our distinction between central and local state ownership in shaping different tunneling behaviors, which has implications for other Asian economies. As noted by Li and colleagues (2014), both central and local SOEs are prevalent in many Asian economies such as India and Vietnam. However, it is not clear whether the different incentives structures and tunneling behaviors articulated in our paper can be readily applied to these countries, which have different sociopolitical systems from China. Thus, we call for more research to understand the nuances involved in different types of SOEs with respect to their tunneling behaviors in other emerging economies. Such research will go a long way toward enriching our knowledge about the varieties of state capitalism across the world (Li et al., 2014).

Third, while this study reveals a subtle link between PP and PA conflicts, this is only a 
preliminary step toward fully understanding the link. Future research may adopt more innovative research designs and collect more detailed data to continue exploring the dynamic interactions between controlling shareholders and company management alongside institutional reforms in China and other emerging economies. Researchers may attempt to identify the conditions under which the collusion can sustain itself in varying institutional contexts. For example, the role of professional management in family-controlled public corporations warrants particular attention. Additionally, the capture of managerial rents may manifest itself in other forms, such as high executive salaries and/or generous remuneration packages. While inadequate information disclosure in China prevents us from investigating this aspect in the current paper, this can be an interesting topic for future studies to explore.

Fourth, in this paper we only focus on the formal aspect of institutional environments. However, it is well known that informal institutions such as culture, religion, and social norms can also affect corporate governance in general, and shareholder behaviors in particular (Coffee, 2001; Sauerwald \& Peng, 2013). We hope future research will explore if and how certain aspects of informal institutions interact with formal institutions, corporate managers, and controlling shareholders in the context of PP conflicts.

Finally, while the empirical measure of tunneling used in our paper is an established one in studies of PP conflicts in China, we acknowledge that there is some noise in the ORECTA measure itself because not every unit of other receivables is an indicator of tunneling. Also, ORECTA does not capture all dimensions of tunneling, which is a common challenge in most tunneling research in China and other emerging economies. For instance, controlling shareholders can undertake complex related-party transactions with their listed subsidiaries to tunnel funds. However, as the carve-out listing process discussed earlier, recurring 
related-party transactions in China can also be a natural part of the businesses between listed subsidiaries and their parent companies (Lo, Wong, \& Firth, 2010). Moreover, related-party transactions can be a double-edged sword in the sense that controlling shareholders can either tunnel funds from or inject cash into the focal listed firms through these transactions (Jian \& Wong, 2010; Sun et al., 2011). In other words, high volumes of these transactions can indicate either severe tunneling or propping-up by controlling shareholders. To determine which case is true, we need to know if the price in each transaction is above or below the normal price in a comparable “arm's-length” transaction. Unfortunately, we do not have such information for our companies, so we must leave it as a challenge for future research to ferret out sneakier ways of tunneling in China and other institutional contexts.

\section{Conclusion}

Tunneling is a ubiquitous agency problem in emerging economies. Building on a contextualized agency-theoretic approach, we have examined the direct and joint effects of owner identity, managerial agency problem, and subnational institutional environments on the severity of tunneling in China. Our study unravels the interplay among the three elements in shaping tunneling, and we hope future research continues this inquiry in China and other institutional contexts. 


\section{References}

Anderson, R. \& Reeb, D. 2004. Board composition: Balancing family influence in S\&P 500 firms. Administrative Science Quarterly, 49(2): 209-237.

Aguilera, R. V., Filatotchev, I., Gospel, H., \& Jackson, G. 2008. An organizational approach to comparative corporate governance: Costs, contingencies, and complementarities. Organization Science, 19(3): 475-492.

Ang, J. S., Cole, R. A., \& Lin, J. W. 2000. Agency costs and ownership structure. Journal of Finance, 55(1): 81-106.

Bae, K., Kang, J., \& Lee, I. 2006. Business groups and tunneling: Evidence from private securities offerings by Korean Chaebols. Journal of Finance, 61(5): 2415-2449.

Baumol, W. J. 1990. Entrepreneurship: Productive, unproductive, and destructive. Journal of Political Economy, 98(5): 893-921.

Brødsgaard, K. E. 2012. Politics and business group formation in China: The Party in control? China Quarterly, 211: 624-648.

Chan, H. S. 2004. Cadre personnel management in China: The Nomenklatura system, 1990-1998. China Quarterly, 179: 703-734.

Coffee, J. C. 2001. Do norms matter? A cross-country evaluation. University of Pennsylvania Law Review, 149(6): 2151-2177.

Cuervo-Cazurra, A. 2006. Business groups and their types. Asia Pacific Journal of Management, 23(4): 419-437.

Dharwadkar, R., George, G., \& Brandes, P. 2000. Privatization in emerging economies: An agency theory perspective. Academy of Management Review, 25(3): 650-669.

Ding, Y., Zhang, H., \& Zhang, J. 2007. Private vs state ownership and earnings management: Evidence from Chinese listed companies. Corporate Governance: An International Review, 15(2): 223-238.

Djankov, S., La Porta, R., Lopez-de-Silanes, F., \& Shleifer, A. 2008. The law and economics of self-dealing. Journal of Financial Economics, 88(3): 430-465.

Du, J., Lu, Y., \& Tao, Z. 2008. Economic institutions and FDI location choice: Evidence from US multinationals in China. Journal of Comparative Economics, 36(3): 412-429.

Durnev, A. \& Kim, E. H. 2005. To steal or not to steal: Firm attributes, legal environment, and valuation. Journal of Finance, 60(3): 1461-1493.

Faccio, M., Lang, L. H. P., \& Young, L. 2001. Dividends and expropriation. American Economic Review, 91(1): 54-78. 
Fan, G., Wang, X., \& Zhu, H. 2011. National Economic Research Institute Index of Marketization of China's Provinces. Beijing: Economic Science Press.

Feinerman, J. V. 2007. New hope for corporate governance in China? China Quarterly, 191: 590-612.

Firth, M., Rui, O. M., \& Wu, W. 2011. The effects of political connections and state ownership on corporate litigation in China. Journal of Law and Economics, 54(3): 573-607.

Franks, J., Mayer, C., \& Rossi, S. 2009. Ownership: Evolution and regulation. Review of Financial Studies, 22(10): 4009-4056.

Gold, T., Guthrie, D., \& Wank, D. (Eds.) 2002. Social connections in China: Institutions, culture, and the changing nature of guanxi. Cambridge: Cambridge University Press.

Green, S. 2003. The development of China's stock market, 1984-2002: Equity politics and market institutions. London: RoutledgeCurzon.

Haß, L. H., Johan, S., \& Müller, M. A. 2016. The effectiveness of public enforcement: Evidence from the resolution of tunneling in China. Journal of Business Ethics, 134(4): 649-668.

Hausman, J. A. 1978. Specification tests in econometrics. Econometrica, 46(6): 1251-1271.

Hu, H. W. \& Cui, L. 2014. Outward foreign direct investment of publicly listed firms from China: A corporate governance perspective. International Business Review, 23(4): 750-760.

Hu, H. W., Tam, O. K., \& Tan, M. G. 2010. Internal governance mechanisms and firm performance in China. Asia Pacific Journal of Management, 27(4): 727-749.

Huang, Y. 2002. Managing Chinese bureaucrats: An institutional economics perspective. Political Studies, 50(1): 61-79.

Jensen, M. C. \& Meckling, W. H. 1976. Theory of the firm: Managerial behavior, agency costs, and ownership structure, Journal of Financial Economics, 3(4): 305-360.

Jian, M. \& Wong, T. J. 2010. Propping through related party transactions. Review of Accounting Studies, 15(1): 70-105.

Jiang, F. \& Kim, K. A. 2015. Corporate governance in China: A modern perspective. Journal of Corporate Finance, 32: 190-216.

Jiang, G., Lee, C. M. C., \& Yue, H. 2010. Tunneling through intercorporate loans: The China experience. Journal of Financial Economics, 98(1): 1-20.

Johnson, S., La Porta, R., Lopez-de-Silanes, F., \& Shleifer, A. 2000. Tunneling. American Economic Review, 90(2): 22-27. 
La Porta, R., Lopez-de-Silanes, F., \& Shleifer, A. 1999. Corporate ownership around the world. Journal of Finance, 54(2): 471-518.

La Porta, R., Lopez-de-Silanes, F., Shleifer, A., \& Vishny, R. 2000. Investor protection and corporate governance, Journal of Financial Economics, 58(1-2): 3-27.

Li, H. \& Zhou, L-A. 2005. Political turnover and economic performance: The incentive role of personnel control in China. Journal of Public Economics, 89(9-10): 1743-1762.

Li, M. H., Cui, L., \& Lu, J. 2014. Varieties in state capitalism: Outward FDI strategies of central and local state-owned enterprises from emerging economy countries. Journal of International Business Studies, 45(8): 980-1004.

Lieberthal, K. G. \& Lampton, D. M. (Eds.) 1992. Bureaucracy, politics, and decision making in post-Mao China. Berkeley, CA: University of California Press.

Liebman, B. L. \& Milhaupt, C. J. 2008. Reputational sanctions in China’s securities market. Columbia Law Review, 108(4): 929-983.

Lin, L-W. \& Milhaupt, C. J. 2013. We are the (national) champions: Understanding the mechanisms of state capitalism in China. Stanford Law Review, 65(4): 697-759.

Liu, G. \& Sun, P. 2005. The class of shareholdings and its impacts on corporate performance-A case of state shareholding composition in Chinese public corporations. Corporate Governance: An International Review, 13(1): 46-59.

Liu, Q. \& Lu, Z. 2007. Corporate governance and earnings management in the Chinese listed companies: A tunneling perspective. Journal of Corporate Finance, 13(5): 881-906.

Lo, A. W. Y., Wong, R. M. K., \& Firth, M. 2010. Can corporate governance deter management from manipulating earnings? Evidence from related-party sales transactions in China. Journal of Corporate Finance, 16(2): 225-235.

Luo, J-H., Wan, D-F., Cai, D., \& Liu, H. 2013. Multiple large shareholder structure and governance: The role of shareholder numbers, contest for control, and formal institutions in Chinese family firms. Management and Organization Review, 9(2): 265-294.

Peng, M. W. \& Jiang, Y. 2010. Institutions behind family ownership and control in large firms. Journal of Management Studies, 47(2): 253-273.

Peng, M. W. \& Sauerwald, S. 2013. Corporate governance and principal-principal conflicts. In M. Wright, D. Siegel, K. Keasey, \& I. Filatotchev (Eds.), The Oxford handbook of corporate governance: 658-672. Oxford: Oxford University Press.

Qian, M. \& Yeung, B. 2015. Bank financing and corporate governance. Journal of Corporate Finance, 32: 258-270.

Sauerwald, S. \& Peng, M. W. 2013. Informal institutions, shareholder coalitions, and 
principal-principal conflicts. Asia Pacific Journal of Management, 30(3): 853-870.

Schulze, W. S., Lubatkin, M. H., Dino, R., \& Buchholtz, A. K. 2001. Agency relationships in family firms: Theory and evidence. Organization Science, 12(2): 99-116.

Shi, W., Sun, S. L., \& Peng, M. W. 2012. Sub-national institutional contingencies, network positions, and IJV partner selection. Journal of Management Studies, 49(7): 1221-1245.

Shih, V., Adolph, C., \& Liu, M. 2012. Getting ahead in the Communist Party: Explaining the advancement of central committee members in China. American Political Science Review, 106(1): 166-187.

Shleifer, A. 1998. State versus private ownership, Journal of Economic Perspectives, 12(4), 133-150.

Shleifer, A. \& Vishny, R. W. 1997. A survey of corporate governance. Journal of Finance, 52(2): 737-783.

Singh, M. \& Davidson, W. N. 2003. Agency costs, ownership structure and corporate governance mechanisms. Journal of Banking \& Finance, 27(5): 793-816.

Sun, P., Mellahi, K., \& Liu, G. S. 2011. Corporate governance failure and contingent political resources in transition economies: A longitudinal case study. Asia Pacific Journal of Management, 28(4): 853-879.

Sun, P., Qu, Z., \& Liao, Z. 2018. How and when do subnational institutions matter for R\&D investment? Evidence from the Chinese pharmaceutical sector, IEEE Transactions on Engineering Management, DOI: 10.1109/TEM.2018.2793215

Tam, O. K., \& Hu, H. W. 2006. Supervisory boards in Chinese corporate governance. In L. S. Ho \& R. Ash (Eds.), China, Hong Kong and the world economy: Study on globalization: 327-347. New York, NY: Palgrave-Macmillan.

Wang, H. \& Qian, C. 2011. Corporate philanthropy and corporate financial performance: The roles of stakeholder response and political access. Academy of Management Journal, 54(6): 1159-1181.

Wooldridge, J. M. 2002. Econometric analysis of cross section and panel data. Cambridge: MIT Press.

World Bank. 2008. Doing business in China 2008. Washington, DC: The World Bank Group.

Wu, J., Xu, D., \& Phan, P. H. 2011.The effects of ownership concentration and corporate debt on corporate divestitures in Chinese listed firms, Asia Pacific Journal of Management, 28(1): 95-114.

Xu, D. \& Meyer, K. E. 2013. Linking theory and context: "Strategy research in emerging economies” after Wright et al. (2005). Journal of Management Studies, 50(7): 
1322-1346.

Yafeh, Y. \& Yosha, O. 2003. Large shareholders and banks: Who monitors and how? Economic Journal, 113(484): 128-146.

Yiu, D. W., Chen, X., \& Xu, Y. 2013. Corporate governance in business groups. In M. Wright, D. Siegel, K. Keasey, \& I. Filatotchev (Eds.), The Oxford handbook of corporate governance: 465-488. Oxford: Oxford University Press.

Yiu, D. W., Lu, Y., Bruton, G. D., \& Hoskisson, R. E. 2007. Business groups: An integrated model to focus future research. Journal of Management Studies, 44(8): 1551-1579.

Yiu, D. W., Xu, Y., \& Wan, W. P. 2014. The deterrence effects of vicarious punishments on corporate financial fraud. Organization Science, 25(5): 1549-1571.

Yoshikawa, T. \& Hu, H. W. 2017. Organizational citizenship behaviors of directors: An integrated framework of director role-identity and boardroom structure. Journal of Business Ethics, 143(1): 99-109.

Young, M. N., Peng, M. W., Ahlstrom, D., Bruton, G. D., \& Jiang, Y. 2008. Corporate governance in emerging economies: A review of the principal-principal perspective. Journal of Management Studies, 45(1): 196-220. 
Table 1 Correlation matrix of variables

\begin{tabular}{|c|c|c|c|c|c|c|c|c|c|c|c|c|c|c|c|}
\hline & Variables & Mean & $\begin{array}{l}\text { Std. } \\
\text { Dev. }\end{array}$ & 1 & 2 & 3 & 4 & 5 & 6 & 7 & 8 & 9 & 10 & 11 & 12 \\
\hline 1 & ORECTA & 0.03 & 0.07 & 1 & & & & & & & & & & & \\
\hline 2 & Firm size & 21.41 & 1.18 & $-0.23 *$ & 1 & & & & & & & & & & \\
\hline 3 & Profitability & 0.10 & 1.57 & $-0.35 *$ & $0.13^{*}$ & 1 & & & & & & & & & \\
\hline 4 & Leverage & 0.51 & 0.27 & $0.36^{*}$ & $0.07 *$ & $-0.39 *$ & 1 & & & & & & & & \\
\hline 5 & Ownership concentration & 37.40 & 15.27 & $-0.09 *$ & $0.22 *$ & $0.06^{*}$ & $-0.04 *$ & 1 & & & & & & & \\
\hline 6 & CEO duality & 0.18 & 0.38 & -0.01 & $0.15^{*}$ & $-0.03 *$ & $0.08 *$ & $0.06^{*}$ & 1 & & & & & & \\
\hline 7 & Board size & 9.25 & 1.85 & $-0.08 *$ & $0.31 *$ & $0.05^{*}$ & $0.05^{*}$ & -0.02 & $0.12 *$ & 1 & & & & & \\
\hline 8 & Private & 0.42 & 0.49 & $0.03^{*}$ & $0.13^{*}$ & -0.005 & 0.01 & $0.09 *$ & $0.14^{*}$ & $0.12^{*}$ & 1 & & & & \\
\hline 9 & CSOE & 0.08 & 0.25 & -0.01 & $0.17^{*}$ & -0.0001 & $0.04^{*}$ & $0.05^{*}$ & $0.06^{*}$ & $0.09 *$ & $-0.14^{*}$ & 1 & & & \\
\hline 10 & LSOE & 0.50 & 0.50 & $0.04^{*}$ & $0.32^{*}$ & $-0.03 *$ & $0.10 *$ & $0.20 *$ & $0.24 *$ & $0.22 *$ & $-0.46^{*}$ & $-0.22 *$ & 1 & & \\
\hline 11 & Managerial agency costs & 0.15 & 0.18 & $0.35^{*}$ & $-0.19 *$ & $-0.40 *$ & $0.34^{*}$ & $-0.14^{*}$ & $-0.04 *$ & $-0.07 *$ & $-0.08 *$ & $-0.04^{*}$ & $-0.10 *$ & 1 & \\
\hline 12 & Selling expense ratio & 0.09 & 0.09 & $0.36^{*}$ & $-0.31 *$ & $-0.41 *$ & $0.19^{*}$ & $-0.15^{*}$ & $-0.07 *$ & $-0.11^{*}$ & $-0.06 *$ & $-0.03 *$ & $-0.11 *$ & $0.66^{*}$ & 1 \\
\hline 13 & Marketization & 8.66 & 2.03 & $-0.07 *$ & -0.02 & $0.09 *$ & $-0.10 *$ & $-0.03 *$ & $-0.03 *$ & $-0.14^{*}$ & $-0.12 *$ & -0.01 & $-0.26 *$ & $-0.07^{*}$ & -0.02 \\
\hline
\end{tabular}

Notes: $\mathrm{N}=5,811 . *$ Significant at $5 \%$ level. 
Table 2 Fixed-effect regressions examining the determinants of tunneling in Chinese listed companies, 2005-2010

\begin{tabular}{|c|c|c|c|c|c|c|c|}
\hline & Model 1 & Model 2 & Model 3 & Model 4 & Model 5 & Model 6 & Model 7 \\
\hline Intercept & $\begin{array}{r}0.302 * * * \\
(6.68)\end{array}$ & $\begin{array}{r}0.318^{* * *} \\
(7.06)\end{array}$ & $\begin{array}{r}0.671^{* * * *} \\
(4.43)\end{array}$ & $\begin{array}{r}0.631^{* * *} \\
(4.17)\end{array}$ & $\begin{array}{r}1.107^{* * *} \\
(6.46)\end{array}$ & $\begin{array}{r}1.098 * * * \\
(6.40)\end{array}$ & $\begin{array}{r}0.898^{* * *} \\
(5.33)\end{array}$ \\
\hline Firm size & $\begin{array}{r}-0.014^{* * *} \\
(-6.90)\end{array}$ & $\begin{array}{r}-0.014 * * * \\
(-6.82)\end{array}$ & $\begin{array}{r}-0.03 * * * \\
(-4.37)\end{array}$ & $\begin{array}{r}-0.028 * * * \\
(-4.08)\end{array}$ & $\begin{array}{r}-0.018 * \\
(-2.22)\end{array}$ & $\begin{array}{r}-0.018^{*} \\
(-2.21)\end{array}$ & $\begin{array}{r}-0.006 \\
(-0.71)\end{array}$ \\
\hline Profitability & $\begin{array}{r}-0.0005^{* * *} \\
(-6.89)\end{array}$ & $\begin{array}{r}-0.0004^{* * *} \\
(-6.69)\end{array}$ & $\begin{array}{r}0.005^{* * *} \\
(9.38)\end{array}$ & $\begin{array}{r}0.005^{* * *} \\
(10.05)\end{array}$ & $\begin{array}{r}-0.001^{* * *} \\
(-5.45)\end{array}$ & $\begin{array}{r}-0.001^{* * *} \\
(-5.37)\end{array}$ & $\begin{array}{r}0.006^{* * *} \\
(10.05)\end{array}$ \\
\hline Leverage & $\begin{array}{r}0.0001 \\
(0.12)\end{array}$ & $\begin{array}{r}0.0001 \\
(0.07)\end{array}$ & $\begin{array}{r}-0.032^{* * * *} \\
(-9.02)\end{array}$ & $\begin{array}{r}-0.031^{* * *} \\
(-8.75)\end{array}$ & $\begin{array}{r}-0.022 * * * \\
(-6.02)\end{array}$ & $\begin{array}{r}-0.022 * * * \\
(-6.03)\end{array}$ & $\begin{array}{r}-0.031^{* * *} \\
(-8.33)\end{array}$ \\
\hline Ownership concentration & $\begin{array}{r}0.0004^{* *} \\
(3.07)\end{array}$ & $\begin{array}{r}0.0004^{* *} \\
(2.74)\end{array}$ & $\begin{array}{r}-0.0002 \\
(-0.46)\end{array}$ & $\begin{array}{r}-0.0002 \\
(-0.47)\end{array}$ & $\begin{array}{r}-0.001^{* *} \\
(-2.51)\end{array}$ & $\begin{array}{r}-0.001^{* *} \\
(-2.54)\end{array}$ & $\begin{array}{r}-0.001^{* *} \\
(-2.78)\end{array}$ \\
\hline CEO duality & $\begin{array}{l}-0.005 \\
(-1.43)\end{array}$ & $\begin{array}{r}-0.006 \\
(-1.53)\end{array}$ & $\begin{array}{r}0.011 \\
(0.92)\end{array}$ & $\begin{array}{r}0.011 \\
(0.89)\end{array}$ & $\begin{array}{r}0.012 \\
(0.87)\end{array}$ & $\begin{array}{r}0.011 \\
(0.83)\end{array}$ & $\begin{array}{r}0.007 \\
(0.52)\end{array}$ \\
\hline Board size & $\begin{array}{r}0.003^{* *} \\
(2.95)\end{array}$ & $\begin{array}{r}0.003^{* *} \\
(2.91)\end{array}$ & $\begin{array}{l}0.003 \\
(0.85)\end{array}$ & $\begin{array}{l}0.002 \\
(0.70)\end{array}$ & $\begin{array}{l}-0.001 \\
(-0.26)\end{array}$ & $\begin{array}{l}-0.001 \\
(-0.32)\end{array}$ & $\begin{array}{l}-0.002 \\
(-0.53)\end{array}$ \\
\hline \multicolumn{8}{|l|}{ Predictors } \\
\hline CSOE (H1) & & $\begin{array}{r}-0.03 * * * \\
(-3.58)\end{array}$ & $\begin{array}{r}-0.041^{*} \\
(-2.32)\end{array}$ & $\begin{array}{r}-0.039 * \\
(-2.22)\end{array}$ & & & \\
\hline LSOE (H1) & & $\begin{array}{l}-0.012 \\
(-1.82)\end{array}$ & $\begin{array}{r}0.011 \\
(0.86)\end{array}$ & $\begin{array}{l}0.012 \\
(0.88)\end{array}$ & $\begin{array}{l}-0.006 \\
(-0.42)\end{array}$ & $\begin{array}{l}-0.001 \\
(-0.09)\end{array}$ & $\begin{array}{l}-0.002 \\
(-0.11)\end{array}$ \\
\hline Managerial agency costs & & & $\begin{array}{r}0.01^{* * *} \\
(12.89)\end{array}$ & $\begin{array}{r}0.011^{* * *} \\
(13.61)\end{array}$ & & & $\begin{array}{r}0.011^{* * *} \\
(13.49)\end{array}$ \\
\hline LSOE $\times$ Managerial agency & costs (H2) & & & $\begin{array}{r}0.02^{* * *} \\
(4.69)\end{array}$ & & & $\begin{array}{r}0.021^{* * * *} \\
(4.65)\end{array}$ \\
\hline Marketization & & & & & $\begin{array}{r}-0.072 * * * \\
(-7.00)\end{array}$ & $\begin{array}{r}-0.074 * * * \\
(-7.23)\end{array}$ & $\begin{array}{r}-0.08^{* * *} \\
(-7.93)\end{array}$ \\
\hline LSOE $\times$ Marketization $(\mathrm{H} 3)$ & & & & & & $\begin{array}{r}0.007^{*} \\
(2.42)\end{array}$ & $\begin{array}{r}0.007^{* *} \\
(2.59)\end{array}$ \\
\hline$R$-square (within) & 0.025 & 0.035 & 0.060 & 0.065 & 0.036 & 0.037 & 0.079 \\
\hline F stats & $19.10^{* * *}$ & $19.85^{* * *}$ & $31.09 * * *$ & $30.31 * * *$ & $18.63 * * *$ & $17.23 * * *$ & $31.58 * * *$ \\
\hline Obs. & 5811 & 5811 & 5811 & 5811 & 5334 & 5334 & 5334 \\
\hline
\end{tabular}

Notes: The $t$-statistics are reported in parentheses with ${ }^{* * *},{ }^{* *}$, and $*$ indicating statistical significance at the $0.1 \%, 1 \%$, and $5 \%$ levels, respectively. Central SOEs (CSOEs) were excluded from Models 5-7, which examined the subnational institutional effect. 
Table 3: Robustness Checks Using Selling Expense Ratio as an Alternative Measure of Managerial Agency Costs

\begin{tabular}{|c|c|c|c|}
\hline & Model 1 & Model 2 & Model 3 \\
\hline Intercept & $\begin{array}{r}0.667 * * * \\
(4.41)\end{array}$ & $\begin{array}{r}0.721^{* * * *} \\
(4.76)\end{array}$ & $\begin{array}{r}0.932 * * * \\
(5.55)\end{array}$ \\
\hline Firm size & $\begin{array}{r}-0.03 * * * \\
(-4.35)\end{array}$ & $\begin{array}{r}-0.03^{* * *} \\
(-4.39)\end{array}$ & $\begin{array}{r}-0.007 \\
(-0.91)\end{array}$ \\
\hline Profitability & $\begin{array}{r}0.006^{* * *} \\
(9.46)\end{array}$ & $\begin{array}{r}0.005^{* * *} \\
(9.99)\end{array}$ & $\begin{array}{r}0.006^{* * *} \\
(10.08)\end{array}$ \\
\hline Leverage & $\begin{array}{r}-0.032 * * * \\
(-9.04)\end{array}$ & $\begin{array}{r}-0.033^{* * *} \\
(-9.27)\end{array}$ & $\begin{array}{r}-0.033^{* * *} \\
(-8.88)\end{array}$ \\
\hline Ownership concentration & $\begin{array}{r}-0.0002 \\
(-0.46)\end{array}$ & $\begin{array}{r}-0.0003 \\
(-0.55)\end{array}$ & $\begin{array}{r}-0.001^{* *} \\
(-2.70)\end{array}$ \\
\hline CEO duality & $\begin{array}{l}0.011 \\
(0.91)\end{array}$ & $\begin{array}{r}0.01 \\
(0.82)\end{array}$ & $\begin{array}{l}0.006 \\
(0.44)\end{array}$ \\
\hline Board size & $\begin{array}{c}0.003 \\
(0.85)\end{array}$ & $\begin{array}{l}0.003 \\
(0.85)\end{array}$ & $\begin{array}{l}-0.001 \\
(-0.37)\end{array}$ \\
\hline \multicolumn{4}{|l|}{ Predictors } \\
\hline CSOE & $\begin{array}{r}-0.041 * \\
(-2.35)\end{array}$ & $\begin{array}{r}-0.126 * * * \\
(-5.26)\end{array}$ & \\
\hline LSOE & $\begin{array}{r}0.012 \\
(0.88)\end{array}$ & $\begin{array}{r}0.01 \\
(0.77)\end{array}$ & $\begin{array}{r}0.0002 \\
(0.01)\end{array}$ \\
\hline Selling expense ratio & $\begin{array}{r}0.009 * * * \\
(12.96)\end{array}$ & $\begin{array}{r}0.009 * * * \\
(13.51)\end{array}$ & $\begin{array}{r}0.01^{* * * *} \\
(13.49)\end{array}$ \\
\hline LSOE $\times$ Selling expense ratio $(\mathrm{H} 2)$ & & $\begin{array}{r}0.27^{* * *} \\
(5.18)\end{array}$ & $\begin{array}{r}0.334^{* * *} \\
(5.79)\end{array}$ \\
\hline Marketization & & & $\begin{array}{r}-0.085^{* * *} \\
(-8.16)\end{array}$ \\
\hline LSOE $\times$ Marketization (H3) & & & $\begin{array}{r}0.018^{* * *} \\
(5.55)\end{array}$ \\
\hline R-square (within) & 0.060 & 0.066 & 0.082 \\
\hline F stats & $31.26^{* * *}$ & $30.99 * * *$ & $32.91^{* * *}$ \\
\hline Obs. & 5709 & 5709 & 5334 \\
\hline
\end{tabular}

Notes: The $t$-statistics are reported in parentheses with $* * *, * *$, and $*$ indicating statistical significance at the $0.1 \%, 1 \%$, and $5 \%$ levels, respectively. Central SOEs (CSOEs) were excluded from Model 3, which examined the subnational institutional effect. 
Table 4 Robustness Checks Adding Board-level Control Variables

\begin{tabular}{|c|c|c|c|c|c|c|c|}
\hline & Model 1 & Model 2 & Model 3 & Model 4 & Model 5 & Model 6 & Model 7 \\
\hline Intercept & $\begin{array}{r}0.440^{* * *} \\
(7.58)\end{array}$ & $\begin{array}{r}0.448^{* * *} \\
(7.74)\end{array}$ & $\begin{array}{r}0.385^{* * *} \\
(6.68)\end{array}$ & $\begin{array}{r}0.390^{* * *} \\
(6.77)\end{array}$ & $\begin{array}{r}0.604^{* * *} \\
(9.35)\end{array}$ & $\begin{array}{r}0.597 * * * \\
(9.26)\end{array}$ & $\begin{array}{r}0.543^{* * *} \\
(8.50)\end{array}$ \\
\hline Firm size & $\begin{array}{r}-0.016^{* * *} \\
(-6.09)\end{array}$ & $\begin{array}{r}-0.016^{* * *} \\
(-5.97)\end{array}$ & $\begin{array}{r}-0.013 * * * \\
(-4.97)\end{array}$ & $\begin{array}{r}-0.013^{* * *} \\
(-4.95)\end{array}$ & $\begin{array}{r}-0.006^{*} \\
(-2.11)\end{array}$ & $\begin{array}{r}-0.006^{*} \\
(-2.09)\end{array}$ & $\begin{array}{l}-0.003 \\
(-0.94)\end{array}$ \\
\hline Profitability & $\begin{array}{r}-0.002^{* * *} \\
(-32.11)\end{array}$ & $\begin{array}{r}-0.002 * * * \\
(-32.00)\end{array}$ & $\begin{array}{r}-0.001^{* * *} \\
(-3.46)\end{array}$ & $\begin{array}{r}-0.001^{* * *} \\
(-3.66)\end{array}$ & $\begin{array}{r}-0.002^{* * *} \\
(-31.58)\end{array}$ & $\begin{array}{r}-0.002 * * * \\
(-31.46)\end{array}$ & $\begin{array}{r}-0.001^{* * *} \\
(-3.16)\end{array}$ \\
\hline Leverage & $\begin{array}{r}-0.004^{* * *} \\
(-3.50)\end{array}$ & $\begin{array}{r}-0.004^{* * *} \\
(-3.51)\end{array}$ & $\begin{array}{r}-0.007 * * * \\
(-5.97)\end{array}$ & $\begin{array}{r}-0.007 * * * \\
(-5.90)\end{array}$ & $\begin{array}{r}-0.004^{* * *} \\
(-3.13)\end{array}$ & $\begin{array}{r}-0.004^{* * *} \\
(-3.12)\end{array}$ & $\begin{array}{r}-0.007 * * * \\
(-5.64)\end{array}$ \\
\hline Ownership concentration & $\begin{array}{r}0.0001 \\
(0.68)\end{array}$ & $\begin{array}{r}0.0001 \\
(0.53)\end{array}$ & $\begin{array}{r}0.0001 \\
(0.37)\end{array}$ & $\begin{array}{r}0.0001 \\
(0.37)\end{array}$ & $\begin{array}{r}-0.0004 \\
(-1.85)\end{array}$ & $\begin{array}{r}-0.0004 \\
(-1.86)\end{array}$ & $\begin{array}{r}-0.0004^{*} \\
(-1.93)\end{array}$ \\
\hline CEO duality & $\begin{array}{r}-0.013 * * \\
(-2.75)\end{array}$ & $\begin{array}{r}-0.013^{* *} \\
(-2.81)\end{array}$ & $\begin{array}{r}-0.013^{* *} \\
(-2.84)\end{array}$ & $\begin{array}{r}-0.013^{* *} \\
(-2.85)\end{array}$ & $\begin{array}{r}-0.013^{* *} \\
(-2.73)\end{array}$ & $\begin{array}{r}-0.013^{* *} \\
(-2.77)\end{array}$ & $\begin{array}{r}-0.013^{* * *} \\
(-2.87)\end{array}$ \\
\hline Board size & $\begin{array}{r}0.0004 \\
(0.35)\end{array}$ & $\begin{array}{l}0.001 \\
(0.45)\end{array}$ & $\begin{array}{r}0.0004 \\
(0.35)\end{array}$ & $\begin{array}{r}0.0004 \\
(0.36)\end{array}$ & $\begin{array}{l}-0.002 \\
(-1.51)\end{array}$ & $\begin{array}{l}-0.002 \\
(-1.53)\end{array}$ & $\begin{array}{l}-0.002 \\
(-1.58)\end{array}$ \\
\hline Independent directors & $\begin{array}{r}-0.001^{*} \\
(-2.38)\end{array}$ & $\begin{array}{r}-0.001 * \\
(-2.27)\end{array}$ & $\begin{array}{r}-0.001 * \\
(-2.44)\end{array}$ & $\begin{array}{r}-0.001 * \\
(-2.40)\end{array}$ & $\begin{array}{r}-0.001 * \\
(-2.17)\end{array}$ & $\begin{array}{r}-0.001 * \\
(-2.12)\end{array}$ & $\begin{array}{r}-0.001 * \\
(-2.35)\end{array}$ \\
\hline Board committees & $\begin{array}{r}-0.006 * * * \\
(-3.91)\end{array}$ & $\begin{array}{r}-0.006 * * * \\
(-3.72)\end{array}$ & $\begin{array}{r}-0.006 * * * \\
(-3.96)\end{array}$ & $\begin{array}{r}-0.006^{* * *} \\
(-3.97)\end{array}$ & $\begin{array}{l}-0.001 \\
(-0.70)\end{array}$ & $\begin{array}{l}-0.001 \\
(-0.50)\end{array}$ & $\begin{array}{l}-0.001 \\
(-0.63)\end{array}$ \\
\hline \multicolumn{8}{|l|}{ Predictors } \\
\hline CSOE (H1) & & $\begin{array}{r}-0.039 * * * \\
(-4.66)\end{array}$ & $\begin{array}{r}-0.029 * * * \\
(-4.39)\end{array}$ & $\begin{array}{r}-0.042 * * \\
(-4.96)\end{array}$ & & & \\
\hline LSOE (H1) & & $\begin{array}{l}-0.007 \\
(-0.91)\end{array}$ & $\begin{array}{l}0.01 * \\
(2.23)\end{array}$ & $\begin{array}{c}0.01 * \\
(2.13)\end{array}$ & $\begin{array}{r}0.00004 \\
(0.01)\end{array}$ & $\begin{array}{l}0.003 \\
(0.52)\end{array}$ & $\begin{array}{l}0.003 \\
(0.56)\end{array}$ \\
\hline \multicolumn{2}{|c|}{ Managerial agency costs (H2) } & & $\begin{array}{r}0.002^{* * *} \\
(9.65)\end{array}$ & $\begin{array}{r}0.002^{* * * *} \\
(9.37)\end{array}$ & & & $\begin{array}{r}0.002^{* * *} \\
(9.67)\end{array}$ \\
\hline \multicolumn{2}{|c|}{ LSOE $\times$ Managerial agency costs (H3) } & & & $\begin{array}{r}0.136^{* *} \\
(2.48)\end{array}$ & & & $\begin{array}{r}0.117^{*} \\
(1.99)\end{array}$ \\
\hline Marketization (H4) & & & & & $\begin{array}{c}-0.04 * * * \\
(-10.04)\end{array}$ & $\begin{array}{r}-0.042^{* * *} \\
(-10.48)\end{array}$ & $\begin{array}{r}-0.045^{* * *} \\
(-11.13)\end{array}$ \\
\hline LSOE $\times$ Marketization $(\mathrm{H}$ & & & & & & $\begin{array}{r}0.004^{* * *} \\
(4.03)\end{array}$ & $\begin{array}{r}0.006^{* * *} \\
(4.83)\end{array}$ \\
\hline$R$-square (within) & 0.234 & 0.239 & 0.256 & 0.257 & 0.259 & 0.263 & 0.284 \\
\hline$F$ stats & $143.62 * * *$ & $117.68 * * *$ & $117.50^{* * *}$ & $108.37 * * *$ & $121.28 * * *$ & $112.21^{* * *}$ & $105.58 * * *$ \\
\hline Obs. & 5067 & 5067 & 5067 & 5067 & 4741 & 4741 & 4741 \\
\hline
\end{tabular}

Notes: The $t$-statistics are reported in parentheses with $* * *, * *$, and $*$ indicating statistical significance below the $0.1 \%, 1 \%$, and $5 \%$ levels, respectively. Central SOEs (CSOEs) were excluded from Models 5-7, which examined the subnational institutional effect. 
Table 5 Robustness Checks Using Unwinsorized Data

\begin{tabular}{|c|c|c|c|}
\hline & Model 1 & Model 2 & Model 3 \\
\hline Intercept & $\begin{array}{r}0.439 * * * \\
(9.23)\end{array}$ & $\begin{array}{r}0.443 * * * \\
(9.33)\end{array}$ & $\begin{array}{r}0.398 * * * \\
(8.17)\end{array}$ \\
\hline Firm size & $\begin{array}{l}0.001 \\
(0.28)\end{array}$ & $\begin{array}{l}0.001 \\
\quad(0.43)\end{array}$ & $\begin{array}{r}0.002 \\
(0.78)\end{array}$ \\
\hline Profitability & $\begin{array}{c}0.004^{*} \\
(2.54)\end{array}$ & $\begin{array}{c}0.0004^{* *} \\
(2.68)\end{array}$ & $\begin{array}{r}-0.0001 \\
(-0.73)\end{array}$ \\
\hline Leverage & $\begin{array}{c}-0.001 \\
(-0.59)\end{array}$ & $\begin{array}{r}-0.001^{* * * *} \\
(-0.60)\end{array}$ & $\begin{array}{l}0.001 \\
(0.86)\end{array}$ \\
\hline Ownership concentration & $\begin{array}{c}-0.0003^{*} \\
(-2.22)\end{array}$ & $\begin{array}{c}-0.0004^{*} \\
(-2.36)\end{array}$ & $\begin{array}{r}-0.0002 \\
(-1.54)\end{array}$ \\
\hline CEO duality & $\begin{array}{r}-0.01^{* *} \\
(-2.78)\end{array}$ & $\begin{array}{r}-0.01^{* *} \\
(-2.83)\end{array}$ & $\begin{array}{r}-0.008^{*} \\
(-2.24)\end{array}$ \\
\hline Board size & $\begin{array}{l}0.0002 \\
(0.19)\end{array}$ & $\begin{array}{l}0.0001 \\
(0.08)\end{array}$ & $\begin{array}{c}-0.001 \\
1.03\end{array}$ \\
\hline Independent directors & & & $\begin{array}{c}-0.008^{* *} \\
(-3.01)\end{array}$ \\
\hline Board committees & & & $\begin{array}{l}-0.007 \\
(-0.55)\end{array}$ \\
\hline \multicolumn{4}{|l|}{ Predictors } \\
\hline LSOE (H1) & $\begin{array}{c}0.001 \\
(0.36)\end{array}$ & $\begin{array}{l}0.002 \\
(0.38)\end{array}$ & $\begin{array}{l}0.005 \\
(1.18)\end{array}$ \\
\hline Managerial agency costs & $\begin{array}{r}0.001^{* * *} \\
(5.87)\end{array}$ & $\begin{array}{r}0.001^{* * *} \\
(6.00)\end{array}$ & $\begin{array}{r}0.001^{* *} \\
(3.16)\end{array}$ \\
\hline LSOE $\times$ Managerial agency costs (H2) & $\begin{array}{r}0.038^{*} \\
(1.99)\end{array}$ & $\begin{array}{l}0.04^{*} \\
(2.09)\end{array}$ & $\begin{array}{r}0.124^{* *} \\
(2.76)\end{array}$ \\
\hline Marketization & $\begin{array}{r}-0.048^{* * *} \\
(-16.71)\end{array}$ & $\begin{array}{r}-0.049 * * * \\
(-17.24)\end{array}$ & $\begin{array}{r}-0.044^{* * *} \\
(-14.18)\end{array}$ \\
\hline LSOE $\times$ Marketization (H3) & $\begin{array}{r}0.006^{* * * *} \\
(5.72)\end{array}$ & $\begin{array}{r}0.006^{* * * *} \\
(5.95)\end{array}$ & $\begin{array}{r}0.007 * * * \\
(7.09)\end{array}$ \\
\hline $\begin{array}{l}R \text {-square (within) } \\
F \text { stats }\end{array}$ & $\begin{array}{r}0.099 \\
40.40^{* * *}\end{array}$ & $\begin{array}{r}0.103 \\
42.17^{* * *}\end{array}$ & $\begin{array}{r}0.109 \\
32.68^{* * *}\end{array}$ \\
\hline Obs. & 5333 & 5334 & 4741 \\
\hline
\end{tabular}

Notes: The $t$-statistics are reported in parentheses with $* * *, * *$, and $*$ indicating statistical significance below the $0.1 \%, 1 \%$, and $5 \%$ levels, respectively. Central SOEs (CSOEs) were excluded from all models because they examined the subnational institutional effect. 